\title{
The idea of incarnation as revisited by Jung, Gadamer and Henry
}

\author{
Paweł SZNAJDER*
}

\begin{abstract}
The idea of incarnation is one of the Christian theological concepts that has exerted the strongest influence on philosophical thought in Europe and which was repeatedly referred to in the twentieth century. The paper presents three reinterpretations of this biblical category. Carl Gustav Jung interprets incarnation in the spirit of Gnosticism, as a process of the psychological individuation of God and man; Hans-Georg Gadamer employs the idea of the inner Word, Verbum interius, to analyse the dogmas of incarnation and the Trinity: seeking in them a solution to the mystery of language; while Michel Henry reaches for the Bible and theology to face anew the issue of human corporeality. These attempts to rethink the theological aspects of the Incarnation of the Son of God reveal the role of this notion in the development of modern psychology, the hermeneutic philosophy of language as well as in anthropology. At the same time, a philosophical reinterpretation of incarnation provides an impulse to rephrase the questions about the relationship between philosophy and theology, as well as faith and reason, good and evil, the relationship between God and man, the mind and the body, as well as speech and thinking. On the other hand, provisional answers to these questions may rekindle theological thought and contribute to the revival of reflection on issues such as the Holy Trinity, the Immaculate and Virgin Conception, or a privation theory of evil. The article provides a starting point for just such a multi-faceted analysis.
\end{abstract}

\section{KEYWORDS}

incarnation; Hans-Georg Gadamer; Michel Henry; Carl Gustav Jung; individuation; language; body

* Ph.D., assistant professor at the Chair of Contemporary of Philosophy, Department of Philosophy and Sociology, Pedagogical University of Cracow, Poland. E-mail: pawel.sznajder196 @gmail.com. 
Divine incarnation is one of the most universal themes to appear in the mythologies of many cultures. Within European culture this notion functions as a recurrent theme in Greek myths, and in later times was to become the axis around which Christian doctrine revolves. A strong connection between European philosophy and Christian tradition has meant that the concept of the Incarnation of the Son of God - the second person of the Holy Trinity has exerted a strong influence on philosophy to this day. On the other hand, it should be noted that the dogma was interpreted by theologians from the perspective of European philosophy, using the language and the methodology developed within it - in this way philosophy itself significantly influenced the expression of the revealed truth in a language available to the human mind. To support this hypothesis, it is enough to mention the connection between the divinity of Christ and the formation of ontological language following the Council of Nicaea (Kelly, 1968: 235-240), the philosophical disputes over substance and nature in the Middle Ages (Cross, 2002: 17), or Gottfried Wilhelm Leibniz's confrontation with the Socinians (Antognazza, 2007: xiii).

The idea of incarnation remained alive in twentieth-century philosophy, and a reflection of it was undertaken by philosophers not only to expand the scope of theological thought, but also for other, sometimes surprising reasons. In my article, I would like to briefly present three philosophical reinterpretations of incarnation as a philosophical trope. The first is the interpretation proposed by Carl Gustav Jung, for whom the Incarnation of Christ is a symbol that shapes human beings' individual personal development. Hans-Georg Gadamer uses the concept in his hermeneutic philosophy to better understand the problem of language. From the perspective of the French phenomenologist, Michel Henry, this idea allows for a clarification of the mystery that is human corporeality, as well as the relationship of the individual with God and with other people.

The discussion of these three philosophical approaches will serve to construct and defend the thesis that the idea of incarnation is a familiar context within many of the disputes ongoing in European philosophy. A full exposition of such a far-reaching thesis obviously requires a much broader study that would take into account the historical perspective as such and be conducted on the basis of a significantly larger number of twentieth-century philosophical currents; such an undertaking is, however, beyond the scope of the present paper.

\section{INCARNATION AND THE PROCESS OF INDIVIDUATION IN THE THOUGHT OF CARL GUSTAV JUNG}

An interpretation of the Biblical story of Christ's birth should be conducted against the backdrop of the whole history of salvation which was most comprehensively presented by Jung in his most personal volume, i.e., Answer 
to Job ${ }^{1}$. It is the fate of that eponymous Biblical hero that becomes the key to understanding the thought of the Swiss psychiatrist, according to whom the Bible is primarily a narrative outlining the intense, even toxic, relationship between God, Yahweh, and Man. This story runs parallel to the history of the world, which is after all a history of God's self-knowing (Burns, 2011: 102). The stories of Job and later of Christ are comprehensible only within the context of the Bible in its entirety. In his work Jung presented such a detailed interpretation.

The first act of the Biblical drama is the creation of the world, when two oppositional elements: light and darkness; good and evil, emerge out of God Himself. It is also the moment when the first-born son of God, i.e., Satan, is brought into the world (Jung, 1959: 146). Man created in the image of God becomes the first victim of this dualism. Adam and Eve give in to temptation from evil and turn away from the Creator. Can they be blamed for their transgression, however? The only real culprit here is God Himself who could not order the world and mankind better (Jung, 2007: 14). We learn more about God's character from his confrontation with his most faithful servant, Job. This well-known narrative held a special significance for Jung. The consequence of God's banal bet with His first-born, which was the ruin of Job undone by the burden of his suffering, and the morally irreproachable attitude of the suffering man, made Yahweh realize how imperfect a moral being $\mathrm{He}$ was to His own material creation. According to Jung, this experience would have much impact on the future of the world and humankind, as Yahweh Himself would desire to become incarnate in order to match his creation in moral terms. It has to underlined that this passionate in wrath, masculine, almost bestial God would not arrive at this realisation on His own. Sophia, wisdom, whom Jung identifies with the female archetype (Anima), prompts Yahweh to embrace this salutary idea (Jung, 2007: 52).

After confronting Job Yahweh, no longer as reckless as at the moment of creation, carefully prepares His incarnation through a series of supernatural deeds, protecting Himself against the intrusion of the dark and evil elements that had occurred in the act of creation. This is effected first and foremost through the virgin and sinless conception of Mary (Jung, 2007: 43-44). According to Jung, however, this denial of darkness and shadow will render the Incarnation imperfect and partial. The sinless Christ did not become fully human. Because of that His sacrifice on the cross cannot fulfil the hope of salvation that mainstream Christians hold. This does not mean that the Crucifixion is devoid of the sense Christianity imbues it with. The moment of

${ }^{1}$ Here, I refer more broadly only to this particular work of the Swiss psychiatrist but it should be noted that reflection on the incarnation and the role of Christ appears throughout Jung's writings, especially in his thinking about the Self archetype (Jung, 1959: 23-71), the Philosopher's stone (Jung, 1968b: 345-431), and Mercurius (Jung, 1983: 217) etc., which, however, could not be included in a short paper like this. 
crucifixion - the suspension of Christ between the good and the evil thief, is extremely important for Jung's reflection, as it means the re-entry of Christ/ God into the power play between good and evil, and the renewed, though as yet not final decision of God to choose good (Jung, 2007: 96-97). This forms the next stage of Yahweh's mental growth (Dourley, 2001: 7-9). The life and death of Christ are not the last acts of God's work, as the incomplete, for sinless Incarnation of Christ requires some supplement. Therefore, the Christian tradition speaks of the sending of the Holy Spirit, the Paraclete, who performs an incessant Incarnation of God into every man, which is exactly how individuation is attained in Jung's view (Jung, 2007: 65).

From Jung's perspective, the person of Christ constitutes the archetype of the Self - the concept superior to the individual "I" (Jung, 1959: 3) which takes into account not only the consciousness of the individual, but also the general, a priori, collective unconsciousness, of which the "I" is a part (Jung, 1959: 5). One of the key truths of Christianity, according to which Christ is the true image of God in us/human beings (Jung, 1959: 37-38), is what Jung reinterprets against the backcloth of analytical psychology, emphasizing the most important functions of the archetype: the unification of the female and male aspects of the self as well as the coming together of the conscious self and the Shadow, that dark component of the human soul which in theology corresponds with the unity of Christ and the Antichrist (Jung, 1959: 36). To fill this gap, Jung used not only the Bible and the tradition of the Church Fathers, but above all Gnostic sources as well as medieval alchemy that aimed at a chemical marriage of opposites and the discovery of the philosopher's stone. These studies prompted him to complete the attributes of the Self already present in the symbol of Christ with attributes antithetical to them, as a result of which the Self is described adequately using the figure of a quaternion of opposites (unitemporal - eternal and unique - universal; or good - evil and spiritual - material/chthonic; Jung, 1959: 62-63). From a psychological point of view, the negation of those antithetical attributes corresponds in the process of individuation to a desperate attempt to reject the real, dark part of human totality, which means "getting rid of the body" and ultimately rejecting one's own humanity. As Jung states in Aion: "In the empirical self, light and shadow form a paradoxical unity” (Jung, 1959: 42). To accept this fact and internally consent to it, requires from one enormous moral courage (Jung, 1959: 9). To embrace the real meaning of incarnation is to reunite one's own self - to perform a marriage of its light and its darkness, the masculine and the feminine, and the conscious and the unconscious. It is not a pleasant process either; on the contrary, seeking contact with the archetypal content of the collective unconscious involves suffering, and even the risk of neurotic or psychotic disorders. However, trying to break the link with the archetype is tantamount to rejecting its protective and saving force (Jung, 1968a: 156-157). 
The Bible, theology both orthodox and "heretical", medieval alchemy, and finally modern psychology all instruct man/human beings on their path to achieving mental individuation. Jung devoted much room to an analysis of these sources in his rich oeuvre. Following his footsteps is no longer an option, however.

\section{INCARNATION OF THE WORD IN HANS-GEORG GADAMER'S PHILOSOPHY OF LANGUAGE}

Gadamer refers to incarnation in several passages, first of all, in his most important work, Truth and method, as well as in his later texts. However, it is not theology itself that interests the German philosopher, but the relationship between incarnation as an idea, language and the hermeneutic experience. Studying the history of language from a concept-driven perspective, he points out that besides the Greek tradition it is the Christian idea of the Incarnation which truly shaped the understanding of what language is (Gadamer, 1990: 422). Gadamer notes something that Jung completely misses, namely, the fact that the Christian concept of the Incarnation is incommensurate with the divine incorporation found in Greek and Roman mythology, where gods take a human form, or with the incarnation of the soul in various bodies during the subsequent stages of their eternal journey (Arthos, 2009: 2). The temporal character of the creation of the world; the crucifixion of the Son of God and the mysterious relationship of the three Persons in the Trinity, i.e., the issues closely connected with Christian Incarnation, do not allow one to think about the idea along the lines set out by the Greek tradition (Gadamer, 1990: 423).

The beginning of the Gospel of John ("In the beginning was the Word [...] And the Word became flesh", John $1,1.14)^{2}$ created an inseparable link between the dogma of the Incarnation, speech and word. For this reason Gadamer fashioned the history of philosophical reflection on that term into the object of his inquiry. The discussion of incarnation is what allowed the idea of language to survive in theology, on the periphery of mainstream Western philosophy, to render its significance all the more visibly in the twentieth century (Gadamer, 1990: 422). In his analysis Gadamer relies predominantly on the thought of Augustine of Hippo, Thomas Aquinas and Nicholas of Cusa, but he equally underlines that the first theological interpretations of the mystery of the Trinity were based on the distinction that Stoics had made between the inner word (logos endiathetos), or non-conceptual thought and the external word (logos proforikos), or thought expressed in writing or speech sounds (Gadamer 1990: 423-424). This distinction was meant to reveal the difference between

${ }^{2}$ All quotes from Holy Bible: English Standard Version (2001), Wheaton: Crossway Bibles. 
imperfect human utterances, and the totality of cosmic logos that cannot be fully expressed in a sentence (Kamesar, 2004: 163). It became very useful for Christians, because it made it possible to express in philosophical terms the non-Greek idea of genesis and the Incarnation of the Son of God (Gadamer, 1990: 423). Since in The prologue to the Gospel John calls Christ the Word, Logos, it can be assumed that in relation to the first Person of the Trinity, God the Father, Christ functions as His internal word (logos endiathetos), and in relation to the created world as an outer word (logos proforikos) (Wierciński, 2010: 23). This stoic principle takes into account the singularity of God, the multiplicity and unity of the Persons within the Trinity, and the sameness of the historical Christ with the Son, the second divine Person. Many of the Church Fathers, as well as Augustine himself, referred to this concept in later times. It was to the Bishop of Hippo, however, that Gadamer owes this close connection between the doctrine of the Incarnation and his own theory of language. Augustine develops the stoic teaching claiming that thinking "a language of the heart" is precisely that inner, purely intellectual word which has not been imbued with any sensual or material form yet (Grondin, 2001: 54). $\mathrm{He}$ claims that the inner word is "quod neque prolativum est in sono, neque cogitativum in similitudine soni" (Augustinus, 1841: 1072). The word of the heart is expressed in a sensual form, not as it really exists, but as the limited potential of the voice, letters, words, sentences, or grammatical forms of national languages allows for it (Grondin, 2001: 54). In the Trinitarian theology of the Bishop of Hippo Gadamer sees a relationship that has become a model for his philosophy of language and thought. Just as a human language is an attempt to utter the inner word of the heart so is the Son the Word the utterance of the Father, the first Person of the Trinity. An analysis of the relationship between the Father and the Son functions in Gadamer's text as a way of determining the interconnectedness of thinking and speech (Gadamer, 1990: 425). What is more fundamental for the understanding of the problem of human speech and the finite situation of man in the world is not the knowledge of the similarities, but the differences between the Word of God and the word of man (Arthos, 2009: 312). To this end, Gadamer employs the thought of Thomas Aquinas.

Aquinas emphasizes that the human word is potential and realises itself over time, in a process, while the divine Word is uttered out of time. God simultaneously understands and creates things in a singular act: there is no difference between His actions and His thoughts (Arthos, 2009: 314). Neither the creation of the world nor the Incarnation of the Son are temporal processes, but, as Gadamer puts it, an "exegesis" of an eternal order in temporality (Gadamer, 1990: 428). Human speech is subject to temporality in that it expresses an inner word in the specific language of a given era and does that though finite, historically conditioned terminology. To fully comprehend it, one needs a temporal distance filled with creative interpretations 
(Gadamer, 1990: 305). Ultimately, however, the tension between understanding a thing and expressing its content through an external word will never be resolved. John Arthos points out that Gadamer follows Thomas in this respect and separates discursive speaking (Latin discursus) from an act of intuition, insight (Latin intuitus), which in the case of the divine mind are identical, but in the finite mind of man remain always insurmountably separate (Arthos, 2009: 314).

The second difference is that unlike the divine Word, the human word is essentially imperfect and limited. The historical figure of Christ is the perfect and full expression of the Word, the second Person of the Trinity. A human word always expresses thoughts in an incomplete, temporary and contingent manner. Human understanding always comes from some introductory, limited insight that provides only a sketchy outline of any given thing. To the divine mind a single intuition provides the sum of all knowing, while man must complete an initial mental picture of things in a circular process of coming to truth (Gadamer, 1990: 271). The word of man requires constant rethinking, re-evaluation and correction, and an act of speaking always leaves a sense of dissatisfaction and unfulfillment. That is why a human word cannot be like the divine: the one and only, single and unique, for it always falls apart into a fragmentary multitude. This difference shows as well that man himself is by nature a being not fully contemporary in what he knows (Gadamer, 1990: 430); that his thinking is dispersed and incapable of grasping any idea with a single insight (Gadamer, 1990: 429).

Finally, Aquinas teaches that God fully expresses his essence and substance through His Word, while human beings learn and speak about things without comprehending them in their entirety, expressing themselves in a way that always remains fragmentary and contingent. Human speech and cognition are necessarily partial and fragmentary. Each act of comprehension reveals some aspects of a thing or an issue, but conceals others at the same time. This difference has serious consequences, as it is through this that Gadamer explains his distrust of the correspondence concept of truth and the philosophy of language based on unequivocal propositions. He is more inclined towards the Heideggerian understanding of truth as unconcealment (aletheia) (Gadamer, 1993: 46). According to Gadamer, contingency of comprehension has also a positive dimension: it creates an infinite space of the spirit that constantly transcends itself, coming up with ever new ideas (Gadamer, 1990: 429-431).

In this way, Thomas's thought on the verbum comes to support Gadamer's hermeneutic project: it strengthens the presupposition that understanding and language are finite on the one hand and that on the other, there is no limit to the senses of the text which, therefore, requires manifold interpretations. Gadamer also notes that hermeneutics owes Thomism one of its most important theses that language is not a tool but a medium of understanding, i.e., the 
mind sees no words, but it sees the word through them (Arthos, 2009: 320). This seems to be a key to understanding one of his most famous statements: "Being that can be understood is language" (Gadamer 2004: 470). ${ }^{3}$

\section{THE ROLE OF INCARNATION IN MICHEL HENRY'S PHILOSOPHY OF THE FLESH}

The Christian notion of incarnation became a subject of inquiry also for the creator of a phenomenology of life, Michel Henry. One of the most important areas of his philosophical reflection were human corporeality and subjectivity. Towards the end of his life, Henry would seek a supplement to his thinking and a confirmation of his insights in the Bible and Christian theology.

How does Henry understand the human flesh, one of the most significant terms in his philosophical vocabulary? It is impossible to make a brief synthesis of the French philosopher's reflection on the flesh and its relation with subjectivity. A detailed analysis of this issue is undertaken, e.g., by Monika Murawska in her work Filozofowanie z zamkniętymi oczami. Fenomenologia ciała Michela Henry'ego [Philosophy with closed eyes: Michel Henry's Phenomenology of the Flesh] (Murawska, 2011: 86-101). This volume remains a seminal reading from the perspective of this argument, as the main principles of Henry's approach are presented from a position influenced by Murawska: she points to a most significant distinction made in Henry's Incarnation, where he discusses two types of corporeality (Murawska, 2011: 80). The first is called le corpse, the body. This is a motionless solid, a physical object that we find in the outside world. The body does not experience, love or desire anything, unlike what is referred to as la chair, the body that experiences and expresses itself, suffers and experiences pleasure, the body that always remains individual, and our own. This body (flesh) is our experience of materiality that also feels as something external to itself (O'Sullivan, 2006: 94). Our own corporeality is given to us originally, and we experience it from within ourselves. This experience prepares us and to some extent enables us to understand and accept the mystery of Christ's Incarnation (Henry, 2010: 36).

While taking into consideration the distinction between the body and living flesh, it should be emphasized that the Incarnation, defined as the transformation of the Word of God into a single flesh is not the same as becoming a single body. In the latter case, the acceptance of the human condition by Christ would mean the adoption of the condition of the world, which in turn implies that the human condition is the condition of the world and the body, and consequently that the very existence of a human being is an assembly of

\footnotetext{
3 "Sein, das verstanden werden kann, ist Sprache" (Gadamer, 1990: 478).
} 
a dead object and an animating element, the soul. This, however, would be a wrong assumption (Henry, 2015: 32). Henry clearly states that man has no body but is flesh; all the dualistic attempts at apprehending humankind are amiss.

According to Henry, it is Christianity that paved the way for such an understanding of what it means to be human. It introduced a completely new concept of incarnation that was known neither to the Jews nor to the Greeks. Its central tenet, the Incarnation of Christ and the similarity of his flesh to ours undermines both the earlier and the later philosophical definitions of humanity. Although this moment remains relatively unknown in theology due to the influx of Greek thought in the Middle Ages, early Christianity defined man solely through his corporeality, while for the Greeks, corporality was associated only with the animal, lower aspects of humanity, which had to be transgressed and which one could not be reduced to (Henry, 2015: 11).

Henry articulates to this particular psycho-physical problem in the following words:

The flesh is thus not added to the self as a contingent and incomprehensible attribute, a sort of synthetic adjunct to our being, coming to split it into two opposed and irreconcilable moments. [...] Man does not know dualism. [...] I and the Flesh are one (Henry, 2015: 124).

It is through our corporeality, [or rather] through experiencing suffering and pleasure, that we recognize life as the reality that remains closest to us. Although one cannot speak of any determination or obviousness, such an experience opens us to a recognition of the existence of the Absolute Life, i.e., of God. Henry does go further than that and stipulates not only the existence of Life in itself, recognizing its identicality with God. Owing to the Incarnation of the Word and the Revelation, we possess the knowledge of God that is much more substantial than that provided by classical theology which attributes to God the properties of unity, eternity, omnipotence, but which is not able to assimilate their metaphysical definitions with the experiences of a religious believer. Thanks to the words of Christ, we know that the Christian God is not, as Henry puts it, an "impassible" God, that is, the divine that remains separate from human affairs, deaf to the human voice and worship, and incapable of loving His followers (Henry, 2015: 122). Christian Revelation does not require affirmation of God from human beings, as the only thing that one can claim about Him is that He exists. In the Prologue to his Gospel, John says what God is: "he is Life" (John 1,4, italics mine) (Henry, 2015: 170). In addition, thanks to the historical act of the Word becoming flesh, we can learn the properties that Christ wanted to reveal to humankind through His teaching about God's Kingdom in the Beatitudes. These newly recognized qualities of 
God are satiety, seeing God, laughter, comfort, mercy, joy and cheerfulness. In short, Christ reveals to humankind that God is the ultimate goal of all human desires (Henry, 2010: 62).

The goal of incarnation is something more that an increase in the amount of knowledge about God and His attributes. The fate and the condition of the man in his flesh remain incomprehensible without a consideration of God's influence on the individual self. I would therefore like to end the discussion of Henry's phenomenology of life with a presentation of the categories of human genesis and salvation as well the creation of the Mystical Body of Christ, as Henry understands them.

Christianity sees the beginning of the work of salvation in the miracle of creation. Henry, however, clearly separates the genesis which he does not account for, from "second birth", i.e., the participation of man in absolute life (Henry, 2015: 229). It is second birth, not creation, that becomes the theme of the Book of Genesis which must be understood as the first lecture on the transcendental theory of humanity, i.e., a priori, the pure possibility of being that is human. Life is not an external principle that lends movement to inanimate clay, but an immanent principle that conditions freedom, independence, uniqueness and the flesh of an individual.

From Henry's phenomenological perspective, the Bible underlines the essence of humanity which is life (Henry, 2015: 227-228). The original human condition and the human bond with the absolute life have been shattered, because man is seeking another power that promises him happiness. Man rejects life with its dimensions of suffering and desire which are, however, inscribed in the human condition. This turning away from life is what Henry calls "idolatry". Still, it is not through strength or external power, but through the human condition, i.e., the suffering, the guilt and endless failure that man opens himself up to the experience of life:

By showing him the nothingness of his own condition, sin at the same time shows the sinner that no living being could live from a life that is nothing; that silently, always, this Life streams forth in him and makes him live, despite his nothingness; and that the possibility of salvation, for the sinner himself and for him more than anyone else, rests on the unique and absolute Life (Henry, 2015: 177).

Thus, Henry reveals the inseparable relationship of human life with the absolute life, the God who is not a transcendent God; the God who remains distant, but closer to man than he is to himself (Henry, 2015: 173-177). Salvation as such is based on the Filial condition, i.e., the condition of the transcendental man, initially shared by all humans. As Henry claims after Irenaeus of Lyon, salvation restores the human condition, weakened by idolatry (Henry, 2015: 246). The Incarnation of the Word in our finite flesh serves to allow 
us to find a lost relationship with God and even to deify man (Henry, 2015: 231). The moment, in which that lost condition becomes restored, is the death of Christ, read as His acceptance of the final consequences of becoming flesh (Henry, 2015: 234).

Henry's vision includes not only the relationship between man and the incarnate life, as the horizon of incarnation encompasses the question of relations with other people. The other obviously possesses an objective/substantive body, a worldly body, however, as Henry emphasizes, this body is always perceived not as a worldly body, or an object, but as what is "inhabited' by the flesh" (Henry, 2015: 162). Such sensual qualities as eye colour or softness of hair are available to the human senses, but the other's body is sensual also in a different way. The eyes of the other are the eyes that see, the hands are the hands that touch. Simply put, the body of the other is transfused with various intentions, it is a hotbed of desires and strivings that cannot be objectified (Henry, 2015: 152-153). And yet, the body of the other is "like an insurmountable wall" (Henry, 2015: 242), writes Henry. He does not find a satisfactory solution to the problem of the possibility of experiencing the other in the history of philosophy or in earlier phenomenology (Henry, 2015: 237-242). His own philosophy seems, at first glance, to be powerless. It is only the act of interweaving the phenomenology of the flesh with the phenomenology of incarnation that allows him to perceive the relationship conditioning any interpersonal connection:

The inevitable reference the phenomenology of flesh makes to the phenomenology of Incarnation presents us with the following evidence: Every relations from one's Self to another Self requires as its point of departure not this Self itself, an I [moi] - my own or the other's - but their common transcendental possibility, which is notbing other than the possibility of their relation itself: absolute Life (Henry, 2015: 243; italics M.H.).

Such a relationship requires recognising the precondition for the Other's experience, i.e., "being-with", which for Henry means being in God, the absolute Life (Henry, 2015: 243). This idea is not just a meaningless abstract for Henry, as it translates into a concrete experience:

The content of every community is all that belongs to Life and has its possibility in it. Suffering, joy, desire, or love each carry a gathering power infinitely greater than what one attributes to "Reason" (Henry, 2015: 244).

Henry discovers the most comprehensive concept of intersubjectivity in the Roman Catholic notion of the Mystical Body of Christ, in which the Word Incarnate unites all the deified in one body, making its members one, common human person (Henry, 2015: 250-251). Thus, Incarnation is the transcendental condition of all interpersonal relationships. 
Michel Henry finds in the concept of incarnation a supplement to his own phenomenology of life and an answer to larger questions significant for philosophy as such: the definition of man and his condition, the possibility of a relationship with God and other human beings. Needless to say, these answers go beyond the regions that can be subjected to a purely philosophical critique.

\section{CONCLUSION}

The above sketch of three perspectives reconsidering the idea of incarnation in contemporary philosophy may give the false impression of a colourful, incoherent mosaic. Yet, to fully synthesize these three approaches would be an impossibly complex task now, and was not my intention. However, thanks to Jung, Gadamer and Henry it becomes apparent that the concept of incarnation seems to be an often overlooked context as well as a source of a number of current philosophical issues: each of these philosophers built their own individual anthropological thought based on that very notion. Jung emphasizes the development and individuation of the self and the need to order its relationship with the archetypal unconscious inherited from its ancestors. Gadamer underlines the importance of the traditions tied with the community, the language and universal logos in which an individual is immersed. Henry presents a picture of a God-like human being who, thanks to the Incarnation of Christ, is able to establish a relationship with the immanent God and to enter into a dialogue with other people.

My article points to the moments of mutual complementation of these three horizons, created, after all, in distinct historical contexts, with the use of different methods. Therefore, despite a measure of incommensurability in these three approaches, it is possible to pint to a possibility of some hermeneutic agreement, especially where they emphasize the tension between some universal reality, i.e. God or the divine Word, and Its temporal and bodily appearance in time, in a finite, embodied and limited form.

From the perspective shared by both Gadamer and Henry, the concept of incarnation shaped the European understanding of language and speech, thinking and conceptualization. This influence, as well as its philosophical consequences, have been almost completely disregarded in the contemporary sciences and the philosophy of language. The reception of the philosophy of language based on a theology of incarnation could contribute to the revival of the Humanities, undervalued and complex-ridden in comparison to "pure science".

The idea of incarnation as Jung presents it has also been pushed to the margins of mainstream theology. According to him, the real meaning of incarnation, the ability to undergo a "metamorphosis" transforming the spirit of a human being, was pushed out by official Christian doctrine and functioned 
on its periphery, in alchemy, astrology, magic and finally in modern psychology. Apart from the role the idea of incarnation plays in individualisation and the eternal problem of the existence of good and evil, which Jung discusses in his works in this context, his thought opens a very interesting discourse in European philosophy, practiced, among others, by Harold Bloom (Bloom, 2005: 217-230). Peter Sloterdijk calls it theopsychology, a form of knowing that attempts to study the phenomenon of the divine Self, as it appears in the holy volumes of various religions, employing the tools of modern psychology (Sloterdijk, 2015: 24).

Apart from Jung's criticism of mainstream Christianity, it seems that it can also be safely concluded that the continuation of research on the concept proposed in this article, as well as other contemporary approaches rethinking incarnation, e.g., feminist (Mulder, 2006: 5-6), or postmodern perspectives (Engel, 2008: 468-477), could contribute to the contemporary understanding of the Incarnation of Christ with Christian denominations.

My article shows a mutual conditioning of these two discourses: the influence of theological tradition on contemporary philosophical thought on the one hand, and a possible looping or feedback, the reinterpretation of the theological doctrine in the light of contemporary philosophy on the other. In the history of European culture this relationship has proved to be fruitful and creative on many an occasion and it seems that even now it can be conducive to an inspiring theological and philosophical debate.

Trans. Anna KOWALCZE-PAWLIK

\section{BIBLIOGRAPHY}

Antognazza, M.R. (2007). Leibniz on the Trinity and the Incarnation. Reason and revelation in the seventeenth century. New Haven: Yale University Press.

Arthos, J. (2009). The inner word in Gadamer's bermeneutics. Notre Dame: University of Notre Dame Press.

Burns, C.P.E. (2011). Jung's engagement with Christian theology. In: K. Bulkeley \& C. Weldon (Eds.). Teaching Jung. Oxford-New York: Oxford University Press.

Augustinus. (1841). Opera omnia. (J.-P. Migne, Ed.). Paris.

Bloom, H. (2005). Jesus and Yabweh: the names divine. New York: Riverhead Books.

Cross, R. (2002). The metaphysics of the Incarnation. Thomas Aquinas to Duns Scotus. OxfordNew York: Oxford University Press.

Dourley, J.P. (2001). Revisioning Incarnation: Jung on the relativity of God. Shim-Song Yon-Gu: Journal of the Korean Jung Institute, 1(16), 1-19.

Engel, U. (2008). Philosophy in the light of Incarnation. Gianni Vattimo on kenosis. New Blackfriars, 89(1022), 468-477.

Gadamer, H.-G. (1990). Gesammelte Werke. Hermeneutik I. Wabrheit und Methode. Grundzüge einer philosopbischen Hermeneutik (vol. 1). Tübingen: Mohr Siebeck. 
Gadamer, H.-G. (1993). Was ist Wahrheit? (pp. 44-56). In: H.-G. Gadamer. Gesammelte Werke. Hermeneutik II. Wabrbeit und Methode. Tübingen: Mohr Siebeck.

Gadamer, H.-G. (2004). Truth and method. (J. Weinsheimer \& D.G. Marshall, Trans.). London-New York: Continuum.

Holy Bible: English Standard Version (2001). Wheaton: Crossway Bibles.

Grondin, J. (2001). Einfübrung in die philosophische Hermeneutik. Darmstadt: Wiss. Buchges.

Henry, M. (2010). Stowa Chrystusa. (K. Mrówka, Trans.). Tarnów: Wydawnictwo Diecezji Tarnowskiej Biblos.

Henry, M. (2015). Incarnation: a philosophy of flesh. (K. Hefty, Trans.). Evanston: Northwestern University Press.

Jung, C.G. (1959). Aion. Researches into the phenomenology of the Self. (R.F.C. Hull, Trans.). New York: Pantheon Books.

Jung, C.G. (1968a). The archetypes and the collective unconscious. (R.F.C. Hull, Trans.). London: Routledge.

Jung C.G. (1968b). Psychology and alchemy. (R.F.C. Hull, Trans.). New York: Princeton University Press.

Jung C.G. (1983). Alchemical studies. (R.F.C. Hull, Trans.). Princeton: Princeton University Press.

Jung, C.G. (2007). Answer to Job. (R.F.C. Hull, Trans.). London-New York: Routlege.

Kamesar, A. (2004). The Logos Endiathetos and the Logos Prophorikos in allegorical interpretation: Philo and the D-Scholia to the Iliad. Greek, Roman and Byzantine Studies, 44(2), 163-181.

Kelly, J.N.D. (1968). Early Christian doctrines. London: Adam \& Charles Black.

Mulder, A.-C. (2006). Divine Flesh, Embodied Word: "Incarnation" as a bermeneutical key to a feminist theologian's reading of Luce Irigaray's work. Amsterdam: Universitet van Amsterdam.

Murawska, M. (2011). Filozofowanie z zamkniętymi oczami: fenomenologia ciała Michela Henry'ego. Wrocław: Wydawnictwo Uniwersytetu Wrocławskiego.

Sloterdijk, P. (2015). God's zeal: The battle of the three monotheisms (W. Hoban, Trans.). Cambridge: Cambridge Polity.

O'Sullivan, M. (2006). Michel Henry: Incarnation, barbarism, and belief: An introduction to the work of Michel Henry. Oxford-New York: Peter Lang.

Wierciński, A. (2010). Hermeneutics between philosopby and theology: The imperative to think the incommensurable. Berlin: LIT. 